\title{
Filmography and synopses
}

\author{
Salto al vacío (Jump into the Void) 1995, 85 mins
}

Produced by: Daniel Calparsoro, Fernando Colomo

Executive Producer: Enrique Fernández Ayuso

Director of Photography: Kiko de la Rica

Editor: Pite Piñas

Screenplay: Daniel Calparsoro

Leading players: Alex (Najwa Nimri), Javi (Roberto Chalu), Esteban (Alfredo Villa), Toño (Ion Gabella), Juáncar (Karra Elejalde), Alberto (Kandido Uranga), Luis (Saturnino García), Fati (Carla Calparsoro), María (Mariví Bilbao), Eva (Noemí Parra)

Alex and fellow gang members Javi, Toño and Esteban drive to a waste dump with a policeman they have kidnapped after a robbery that goes wrong. On arrival at the dump, Javi and Esteban argue; Toño shoots the policeman dead. The gang drive off; the bickering continues in the car until Toño, who is driving, crashes the car in sheer rage. The gang go their separate ways but not before Javi and Alex share a kiss. At home, Alex listens to the different demands of her family. Her mother tells her that Javi would find her more attractive if she made more of an effort with her looks: subsequently Alex goes to the bathroom and begins to apply make-up. Alex's uncle Alberto comes to the family flat to ask her to work for him as a bodyguard at a meeting; he and her father Luis argue violently, and Alex intervenes by pointing a gun at her father. The gang meet in Esteban's caravan; two men subsequently arrive to carry out a gun deal with Esteban. The three men fight, and Esteban's finger is cut off; the rest of the gang intervene. Later, Alex carries out a series of drug deals before meeting her brother Juáncar and talking to him of her hopes with Javi. She then meets with her uncle at a dogfight, shooting dead two men who beat him up. She meets Javi at a party; the two begin to kiss but then Javi reveals he is impotent. Subsequently, Esteban - now working for the gun runners - shoots Juáncar dead. Alex vows revenge, paying no attention to Javi, who is now proposing they go away together and set up a bar. Javi walks away and leaves her alone in the gathering mist. 


\section{Pasajes (Passages) 1996, 90 mins}

Produced by: Agustín Almodóvar

Director of Photography: Kiko de la Rica

Editor: José Salcedo

Music: Alberto Iglesias

Screenplay: Daniel Calparsoro

Leading players: Gabi (Najwa Nimri), Carmina (Charo López), Manu (Alfredo Villa), Butano (Ion Gabella), Gema (Carla Calparsoro)

Gabi and Gema carry out an apartment robbery. The police are alerted; Gabi escapes the apartment building but Gema is shot dead. Manu and Butano wander round the dockside discussing Butano's hopes of boxing success. At their squat they find Gabi, who tells them of Gema's death. Butano is distraught, while Manu accuses Gabi of using people. As Gabi walks the streets, she catches sight of a woman, Carmina, walking in high heels. Gabi begins to stalk her, following Carmina to her home and subsequently to her job as a hospital cleaner, from which she is fired. Gabi moves into Carmina's flat, begins an affair with her and induces her into the world of crime. But when the couple rob a fish warehouse, Gabi is jealous at Carmina's flirtation with the warehouse watchman and the two women quarrel. After a subsequent house robbery Gabi takes Carmina to buy the green marbled shoes about which Gabi has fantasised. The couple then meet with Manu and Butano, and the four plan the robbery of a bar. As the robbery is carried out, Gabi abandons Carmina and goes with the two men to their hideout, where she attempts to persuade Manu to leave Butano and go abroad with her. The police arrive and Manu dies in a shoot-out; Gabi departs, leaving Butano to weep over Manu's body.

\section{A ciegas (Blindly) 1997, 92 mins}

Produced by: Juan Alexander

Director of Photography: Gonzalo F. Berridi

Editor: José Salcedo

Music: Mario de Benito

Screenplay: Daniel Calparsoro

Leading players: Marrubi (Najwa Nimri), Mikel (Alfredo Villa), Clemente (Ramón Barea), Aitzpea (Elena Irureta), Paquita (Mariví Bilbao), Taxista (Javier Nogueiras), Eneko (Vidal Fernández), Andoni (Víctor Peñas), Reporter (Santiago Ugalde)

Marrubi works in a laundry, watched over obsessively by her boss Clemente. At the end of her shift she goes with her partner Mikel to carry out an ETA assassination at a house in the country. However, instead of shooting dead the owner of the house she shoots her comrade Eneko in the knee, and the house owner subsequently seizes a gun and shoots him dead as well as threatens her. Mikel drives her away to a safe house, where he reports her actions to 
Aitzpea. He takes away the son of himself and Marrubi. The safe house is raided by police; Marrubi escapes and seeks refuge with Clemente. He holds her hostage and forces her to fellate him; in the process she bites his penis and holds him at gunpoint. Mikel comes to Clemente's home looking for Marrubi; Marrubi hides in fear that he has come to kill her, but in fact he has not. Marrubi imprisons Clemente and his housekeeper in bubble wrap and then leaves the flat; she wanders the streets as a riot takes place in response to the death of Eneko. Marrubi subsequently meets Mikel in a station; the two make love but Mikel refuses to leave with her and their son. Meanwhile, Aitzpea waits with the son in the station café. Mikel is ambushed and shot dead by police on the station platform; a shoot-out begins in the café. Aitzpea flees with the son; Marrubi sees them and follows. As she approaches Aitzpea, the latter points a gun at her but then lets it fall; she allows Marrubi to leave with her son.

\section{Asfalto (Asphalt) 2000, 90 mins}

Produced by: José María Lara

Director of Photography: Josep M. Civit

Editor: Julia Juaniz

Music: Nacho Mastretta, Najwajean

Screenplay: Daniel Calparsoro, Frank Palacios, Santiago Tabernero

Leading players: Lucía (Najwa Nimri), Charly (Juan Diego Botto), Chino

(Gustavo Salmerón), Antonio (Alfredo Villa), Clarita (Antonia San Juan)

Charly and Chino meet Lucía, Chino's girlfriend, and take her back to Charly's place where Chino and Lucía make love. Chino invites her to help in the raid they are about to carry out; Charly is annoyed and the trio argue. They go to the flat of a Frenchman; Chino attacks the Frenchman and thinks he has killed him. He runs off while Charly and Lucía raid the flat for drugs. The trio agree to meet up later, but Chino does not arrive. Charly begins to show a sexual attraction towards Lucía. He and she go to his home and start to make love, but Chino interrupts them and realises what is going on. Lucía then initiates a sexual threesome. Afterwards Chino is not happy and calls his brother Antonio for help; Antonio, a policeman, organises a raid that results in Charly going to prison. On his release from jail Charly is met by Lucía, who tells him that she and Chino are setting up home together and do not want to see Charly again. Chino has meanwhile joined the police. He wants Lucía to stop dealing in drugs. She agrees to carry out one final deal before quitting, but as she does so she is robbed of her money. Chino subsequently realises that the theft was a setup organised by Antonio. He meets with Charly, and the two then find Lucía, but Antonio catches up with them and starts a quarrel with all three. As they drive along in Chino's car, the argument causes Chino to crash. The trio stagger out of the car, steal another and head away from Madrid into the country. But Chino stops the car, embraces Charly and Lucía 
and then starts to walk back towards the city, while Lucía and Charly head in the opposite direction.

\section{Guerreros (Warriors) 2002, 96 mins}

Produced by: Fernando Bovaira, Enrique López Lavigne

Director of Photography: Josep M. Civit

Editor: Julia Juaniz

Music: Najwajean

Screenplay: Daniel Calparsoro, Juan Cavestany

Leading players: Vidal (Eloy Azorín), Alonso (Eduardo Noriega), Rubio (Rubén Ochandiano), Balbuena (Carla Pérez), Ballesteros (Jordi Vilches), Lucas (Roger Casamajor), Gómez (Iñaki Font), Mónica (Sandra Walhbeck), Marceau (Olivier Sitruck)

In the middle of a battle in a Kosovan town, the power is cut. Meanwhile, Spanish soldiers are working to restore a church near a refugee camp in another part of Kosovo, when one solider, Vidal, goes to rescue a man being tortured. The other soldiers have to intervene and Vidal is reprimanded by Lieutenant Alonso. The troop is then sent to restore power to the Kosovan town of the opening sequence; on the way the peacekeeping forces are ambushed and the Spanish troop retreats. One soldier, Gómez, dies, Rubio is injured, then the interpreter, Mónica, is seriously injured by a landmine. Vidal is sent to rescue her, but smothers her instead. Another soldier, Lucas, dies. The remainder of the retreating soldiers arrive at the town and are imprisoned. Balbuena is raped. Vidal, Balbuena, Rubio and Marceau escape; on the run, they kill a soldier and a farmer, and are then nearly buried in a mass grave. They return to the town just as the light is restored; panicked by gunfire, they are quickly surrounded by the townspeople. Alonso comes to tell them their mission is over.

\section{Ausentes (The Absent) 2005, 9I mins}

Produced by: Juan Alexander

Director of Photography: Josep M. Civit

Editor: Iván Aledo

Music: Carlos Jean

Screenplay: Daniel Calparsoro, Ray Loriga

Leading players: Julia (Ariadna Gil), Samuel (Jordi Mollà), María (Mar Sodupe), Félix (Nacho Pérez), Luis (Omar Muñoz)

Julia, who has failed in her attempt to find a new job, moves to a suburban development with husband Samuel and children Félix and Luis. The suburban development is apparently empty. Julia's unease in her new home is exacerbated by the occasional mysterious appearance of a ghostly woman called María in the house. When Julia visits the maintenance block and a supermarket, she is struck by their emptiness and appears to be pursued 
in both by unknown beings. The more she grows uneasy, the more Samuel and Félix treat her as if she were unwell, until eventually Samuel starts to inject her with drugs and lock her in the house. Eventually, Julia attempts to run away with Luis; Samuel pursues them, and María seizes Luis. Julia then runs Samuel down in their car and chases Félix to the local swimming pool; appearing to be attacked once more by unseen beings, she lashes out frenziedly with a knife. From Félix's point of view, however, we see that she is in fact lashing out at a crowd of bathers. Finally, she falls into the pool. Subsequently, María brings the children to be reunited with their wounded father while Julia stands to one side, isolated. A cut to her point of view reveals that she still sees nobody around her. 